family grave, arguing that the unexpected circumstances of the daughter's death, the distance of Bingham from Gamston and the intention now to create a family grave should constitute exceptional circumstances justifying exhumation.

The chancellor set out the principles governing the application, namely the permanence of Christian burial, as laid down in Re Christ Church, Alsager [1999] Fam 142 and Re Blagdon Cemetery [2002] Fam 299. He touched briefly on the possible conflict of authority between the two decisions and between ecclesial provinces as noted in Re St Chad, Bensham [2016] ECC Dur 2. Following Bensham, the chancellor found that Alsager is binding in the northern province, either as the appellate court of that province or as a decision of a quasibidivisional appellate court with temporal priority over Blagdon. He noted that the factual matrices for what is exceptional differ in Blagdon and Alsager but neither is an exhaustive list of exceptional circumstances. Exceptional circumstances are facts not law and therefore not bound by precedent. In this case, reviewing the various categories of circumstances the chancellor found that the proposal would not create a family grave as one already existed at Bingham, where there was space for the petitioner to be interred. There was no mistake at the time of the burials at Gamston. There were therefore no exceptional grounds justifying exhumation. The faculty was refused. [Catherine Shelley]

\title{
Re Southstoneham Cemetery
}

Winchester Consistory Court: Ormondroyd Ch, 19 February 2018 [2018] ECC Win 2 Exhumation - illegal use of reserved plot

In 1999 the petitioner purchased the exclusive rights of burial for grave plot 107 adjoining that of his late sister. In the intervening years two other adjoining plots were used or reserved by family members, providing a square of family graves. In February 2016 Mrs Sutton's remains were buried in plot 107. When enquiries were made it transpired that council records showed a transfer of the petitioner's reservation, apparently in 1999, from plot 107 to another plot nearby, apparently at the request of the family. It was held that the petitioner had not requested the transfer, which remained unexplained, and the council accepted that it had been at fault in its processes. After lengthy efforts and correspondence, the petitioner now sought the exhumation of Mrs Sutton's remains from plot 107 in order that it would once more be available to him.

The chancellor considered whether the petitioner in fact held exclusive rights of burial in relation to plot 107 in 2016. Although the council register benefitted 
from a presumption of regularity, it was not conclusive proof of the grant of rights of burial. Under the Local Authority Cemeteries Order 1977, exclusive rights of burial are in the nature of a proprietary right; their assignment can only be done by deed or by bequest. Here, the chancellor was satisfied that the petitioner himself had not sought the transfer and therefore no lawful amendment could be made. The register was wrong. Consequently, the 2016 burial had taken place in a plot reserved for someone else. The chancellor did not accept the reasoning in Re Fairmile Cemetery [2017] ECC Oxf 2 that such a step could not amount to a mistake for the purposes of setting aside the presumption of the permanence of Christian burial as set down in Re Blagdon Cemetery [2002] Fam 299. If Mrs Sutton's family and the council had known of the petitioner's pre-existing right to burial in plot 107 they would not have carried out the interment there - they had made a mistake.

The chancellor went on to consider whether exceptional circumstances had been made out such that a faculty should be granted. The petitioner's status as owner of the exclusive rights of burial is a powerful factor in favour of the grant of a faculty. The availability of other suitable plots for Mrs Sutton's remains also militated in favour of the grant. The attitude of the council was irrelevant to the petition. The strong opposition of the Sutton family, including evidence of the impact on existing mental health issues and the risk that Mr Sutton would not live to see a memorial at his wife's grave, weighed against the grant. Given the availability of alternative burial plots very nearby and the option of the burial of the petitioner's remains in his sister's grave, the chancellor found that exceptional circumstances were not made out and a faculty was refused. [RA]

doi:10.1017/So956618X18000820

\section{Re Torrisholme Cemetery}

Blackburn Consistory Court: Hodge Ch, 20 February 2018

[2018] ECC Bla 1

Exhumation - opposition of parent - lapse of time

The petitioner sought a faculty for the exhumation of the remains of her baby son, which had been interred in Lancashire in 2002, for their reburial near her home in West Yorkshire. She had moved to West Yorkshire in 2006. Failing health meant that it was now difficult for her to visit her son's grave as often as she would like and his father had also moved to the area, so that there were now no family members living near the grave. The father strongly objected to the exhumation, saying that he was appalled and disgusted at the suggestion that his son's remains should be disturbed after 15 years to be moved to a place with which he had had no connection. The chancellor applied the test in Re Christ Church, 